\title{
ДУХОВНО-ЕСТЕТИЧНЕ ВИХОВАННЯ МАЙБУТНІХ МУЗИЧНО-ПЕДАГОГІЧНИХ ПРАЦІВНИКІВ
}

\author{
Чжоу Мінь \\ здобувачка третього (освітньо-наукового) рівня вищої освіти кафедри \\ освітології та інноваційної педагогіки, Харківський національний \\ педагогічний університет імені Г. С. Сковороди, м. Харків, Україна
}

У статті зазначено, що духовно-інтелектуальне виховання є складовою професійної підготовки майбутніх музично-педагогічних працівників. Творіння власних продуктів музичного мистецтва вимагає духовного натхнення й великої сили волі. Розвиток інтелектуального мислення надихає майбутніх музично-педагогічних працівників на творчість, активність, ініціативність, самовираження в конкурсних програмах.

Ключові слова: музичне мистецтво, естетика, виховання, музичнопедагогічний працівник, вокальна майстерність, творчі конкурси.

The article states that spiritual and intellectual education is a component of professional training of future music and pedagogical workers. Creating your own musical art products requires spiritual inspiration and great willpower. The development of intellectual thinking inspires future music and pedagogical workers to creativity, activity, initiative, self-expression in competitive programs.

Key words: musical art, aesthetics, education, music-pedagogical worker, vocal skills, creative competitions.

У професійній підготовці майбутніх музично-педагогічних працівників вагоме місце займає духовно-інтелектуальне виховання як процес передачі молодому поколінню основ духовності й досвіду формування інтелектуальних умінь. Сприйняття красивого, безумовно, пов'язане 3 духовним світом людини. По суті, духовність $є$ ознакою красивого, справжнього, толерантного самовиявлення особистості в житті й професійній діяльності. Музично-педагогічні працівники виконують важливу місію - завдяки музичному мистецтву й власному таланту передають іншій людині різні почуття, розуміння закономірностей розвитку суспільства, тенденцій часового простору, допомагають знайти місце в соціумі та прийняти себе, визнати перемоги й поразки в життєвих ситуаціях. 
Розділ І. Ціннісні орієнтири духовно-інтелектуального виховання, розвиток духовно-інтелектуальних якостей особистості в умовах співпраці й інклюзії

Як зазначають учені Чжоу Цзяньбо, Ян Ченся [1; 2], вокальна музика є засобом духовно-інтелектуального виховання майбутніх музично-педагогічних працівників, оскільки систематичне навчання вокальної музики здійснюється 3 метою всебічного формування музично-педагогічних знань і вмінь здобувачів, музичного чуття, естетики та іншої грамотності, а також спонукає до оцінки, сприйняття досвіду вокального мистецтва як культурної спадщини. На їхню думку, необхідно готувати майбутніх фахівців 3 перспективним баченням розвитку в професійній діяльності, зміцнювати знаннями про вокальні твори та співочими навичками, підвищувати співочий рівень і професійний сценічний досвід виконання вокальних творів.

Якщо в попередньому висловлюванні думок недостатньо зазначено зв'язок музично-педагогічних й інтелектуальних умінь, то наразі $\epsilon$ нагода звернути увагу на таке. Процеси інтеграції широко проникають у освітні процеси, наприклад, поєднання традиційних і нетрадиційних методів, форм організації освітнього процесу. Удосконалення методики викладання вокальної музики в художніх академіях відбувається завдяки різноманітним методам навчання, як: мікронавчальні методи, методи дискусії, методи керівництва та ситуаційно-творчі методи. Поперше, таке поєднання вимагає інтелектуальних умінь розв'язувати складні завдання шляхом пошуку й напруження сили мислення. Подруге, воно підвищує активність та ініціативність здобувачів під час навчання вокалу, посилює їхню суб' єктивність, формує почуття задоволення й самодостатності.

Заслуговує уваги те, що практична діяльність майбутніх музичнопедагогічних працівників у закладах вищої освіти реалізується переважно двома шляхами: перший - музична діяльність, яку організовує кафедри і факультет, включаючи різноманітні звіти та конкурсні заходи, організовані класами та відділеннями, у яких здобувачі можуть брати активну участь, збагачувати сценічний досвід та розкривати професійні здібності, інший — це позауніверситетська практична діяльність. Нині різноманітні заходи - музичні прослуховування, конкурси талантів, культурні вечори, які організовуються в суспільстві, $\epsilon$ дуже змістовними й розвивальними. Вони позитивно впливають на духовно-інтелектуальне виховання молоді.

Наведемо приклад. Національний конкурс професійної майстерності Китаю стає все більш зрілим, але відображена ним проблема 
підготовки талантів у китайській професійній освіті стає все більш очевидною. Національний конкурс професійних навичок $\epsilon$ першим національним конкурсом професійної майстерності, проведеним у Китаї в 2008 році. Виокремимо основні цілі: перша — спрямувати реформування та розвиток суміжних спеціальностей у закладах вищої освіти, ураховуючи стандарти та умови конкурсу; друга - сприяти співпраці між закладами вищої освіти та підприємствами, сприяти інтеграції освіти й виробництва, по-третє - показати поточний рівень викладання, результати викладання та духовний світогляд здобувачів і працівників закладів вищої освіти, роботодавців.

Чжоу Цзямбо [1] пропонує заходи: по-перше, точно визначити цілі підготовки професіоналів вокальної музики, по-друге, поглибити співпрацю й розробити платформу для інтеграції галузі та університету, по-третє, посилити підготовку вчителів вокалу з подвійним дипломом, по-четверте, побудувати диверсифіковану систему навчання вокальної практики.

Отже, духовно-інтелектуальне виховання майбутніх музично-педагогічних працівників пронизує систему їхньої професійної підготовки.

\section{Список використаних джерел:}

1. 周剑波, 江汉艺术职业学院, 全国职业技能大赛对高职声乐专业人才培 养的引导性, 中国文艺家 : 234-235

Чжоу Цзяньбо. Цзянханський професійний коледж мистецтв. Керівництво Національного конкурсу професійних навичок у підготовці професіоналів у професійній музиці. Китайський художник. С. 234-235.

2. 太原市文化艺术学校, 基于艺术院校声乐人才培养的声乐教学开展研 究, 戏剧之家 : 124-125

Ян Ченся. Школа культури та мистецтв Тайюань. Дослідження викладання вокальної музики на основі підготовки вокальних талантів у художніх школах. Драматичний будинок С. $124-125$. 